\title{
Einheit der Kirche im Neuen Testament
}

Dritte europäische orthodox-westliche Exegetenkonferenz in Sankt Petersburg, 24.31. August 2005

Hrsg. v. Anatoly A. Alexeev, Christos Karakolis u. Ulrich Luz u. Mitarb. v. KarlWilhelm Niebuhr

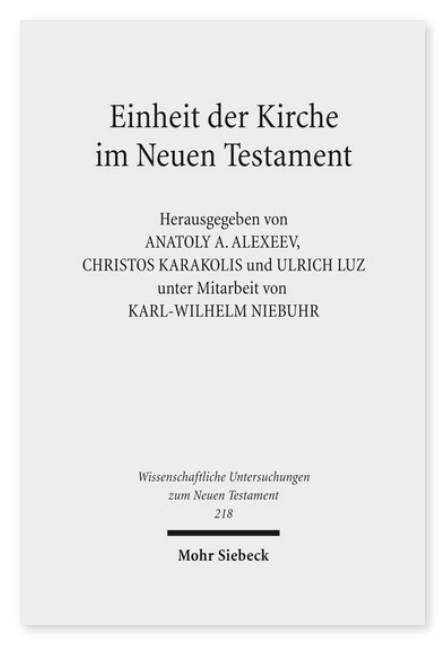

2008. X, 311 Seiten. WUNT I 218

ISBN 978-3-16-151507-1

DOI 10.1628/978-3-16-151507-1

eBook PDF 99,00€

ISBN 978-3-16-149560-1

Leinen $99,00 €$
Der Band gibt die Vorträge der dritten europäischen orthodox-westlichen Exegetenkonferenz vom 24.-31. August 2005 in Sankt Petersburg wieder. Die Konferenz in Sankt Petersburg war der Frage der Einheit und Vielfalt der Kirche nach den Zeugnissen des Neuen Testaments gewidmet. Ein Schwerpunkt liegt auf Beiträgen zum Verständnis der Eucharistie und der Mission in ihrer Bedeutung für die Einheit der Kirche. Daneben werden weitere historische und theologische Fragen zur neutestamentlichen Ekklesiologie sowie wirkungsgeschichtliche Aspekte des Themas behandelt. Zu allen Themenbereichen werden Beiträge aus orthodoxer, katholischer und evangelischer Perspektive geboten.

Die Symposien von orthodoxen und 'westlichen' (evangelischen und katholischen) Neutestamentlern werden seit 1998 durchgeführt und widmen sich methodischen und hermeneutischen Grundfragen der biblischen Exegese. Sie dienen der Kontaktaufnahme und Kooperation zwischen Wissenschaftstraditionen der biblischen Exegese, die bisher weitgehend voneinander isoliert waren.

\section{Inhaltsübersicht}

\section{Einheit der Kirche in der neutestamentlichen Ekklesiologie}

James D.G. Dunn: One Church - many churches - Jannuari Ivliev: Die Kirche Gottes als die eschatologische Realität in der Welt in der paulinischen Tradition - Stelian Tofana: Die Beziehung zwischen der lokalen und universalen Kirche im Licht der ekklesiologischen Terminologie des Neuen Testaments - Loveday Alexander: Community and Canon. Reflections on the Ecclesiology of Acts

II Geschichtliche Vielfalt der Kirche im Urchristentum

Gerd Theißen: Kirche oder Sekte? Über Einheit und Konflikte im frühen Urchristentum - Eleni Kasseluri: Women and Mission in the New Testament

III Eucharistie und Einheit der Kirche

Petros Vassiliadis: The Eucharist as an Inclusive and Unifying Element in the New Testament Ecclesiology - Martin Ebner: »Hütet euch vor dem Sauerteig der Pharisäer ...!« Die Profilierung jesuanischer Tischgemeinschaft im narrativen und semantischen Konzept des Markusevangeliums - Otfried Hofius: Gemeinschaft am Tisch des Herrn. Das Zeugnis des Neuen Testaments - David Horell: Pauline Churches or Early Christian Churches? Unity, Disagreement, and the Eucharist IV Mission und Einheit der Kirche

Hans Kvalbein: Discipleship, Kingdom and Conversion: Aspects from Recent Exegetical Discussion on the Mission of the Church - Armand Puig y Tàrrech: The Mission According to the New Testament: Choice or Need?

V Wirkungsgeschichtliche Aspekte Dmitrij Bumazhnov: Some Ecclesiological Patterns of the Early Christian Period and Their Implications for the History of the Term (Monk) - Alexander Negrov: Understanding the New Testament Church within an Orthodox Hermeneutical Framework

Anatoly A. Alexeev ist Direktor der Bibliotheca Biblica und Professor an der Philologischen Fakultät der Universität St. Petersburg.

Christos Karakolis Born 1968; 1990 Bachelor in Theology; 1990-96 Doctoral studies at the Universities of Thessaloniki, Regensburg and Tübingen; 1996 ThD; since 2005 Assistant Professor at the Faculty of Theology of the University of Athens.

Ulrich Luz (1938-2019) 1957-62 Studium der Theologie in Zürich, Göttingen und Basel; 1970 Dozent für christliche Theologie und Neues Testament in Tokyo; 1972 o. Prof. für Neues Testament in Göttingen; 1980 o. Prof. für Neues Testament in Bern; 2003-19 Prof. emeritus.

Karl-Wilhelm Niebuhr Geboren 1956; 1986 Promotion; 1991 Habilitation; 1994-96 Professor für Biblische Theologie (evangelisch) an der Technischen Universität Dresden; 1997-2022 Professor für Neues Testament an der Friedrich-SchillerUniversität Jena; Präsident des Eastern Europe Liaison Committee (EELC) der Studiorum Novi Testamenti Societas (SNTS). https://orcid.org/0000-0002-8850-7046

Jetzt bestellen:

https://mohrsiebeck.com/buch/einheit-der-kirche-im-neuen-testament-9783161515071?no_cache=1

order@mohrsiebeck.com

Telefon: +49 (0)7071-923-17

Telefax: +49 (0)7071-51104 